\title{
Production of xylanase under solid state fermentation using different agricultural and horticultural residue by Myceliopthora thermophila SH1 (Ascomycota: Chaetomiaceae)
}

\section{Nivedita Sharma, Shruti Pathania* and Shweta Handa}

Dr Y. S. Parmar University of Horticulture and Forestry. Department of Basic Sciences. Nauni, Solan, H. P., India. *Email: shrutipathania89@gmail.com.

\begin{abstract}
An abundant amount of agricultural/horticultural waste were generated from agricultural and industrial processing. However, such wastes usually have a composition rich in sugars, minerals and proteins, and therefore, they should not be considered "wastes" but raw materials for other industrial processes. The purpose of the present work was to optimize the xylanase production by Myceliopthora thermophila SH1 (Ascomycota: Chaetomiaceae) an alkalothermophilic strain isolated from hot spring of Himachal Pradesh under solid state fermentation using different agricultural wastes/horticultural waste as a substrate by enrichment with basal salt medium at temperature $45^{\circ} \mathrm{C}$ after incubating it for 7 days. The highest level of enzymes was produced using rice bran, orange pulp, sugarcane bagasse, wheat straw, wheat bran, apple pomace as a substrate. The secreted extracellular enzyme presented a property that matches the requirement in industrial environment.
\end{abstract}

Keywords: Agricultural residue; Horticultural waste; Xylanase; M. thermophila SH1; SSF.

\section{Introduction}

Thermophilic microorganisms have gained a great deal of attention in the last two decades (Beg et al., 2000). Enzymes produced from these microorganisms are of special interest since these are not usually denatured by high temperature and are even active at elevated temperature. Therefore
Received

February 10, 2016

Accepted

July 26, 2016

Released

December 31, 2016

Open Acess Full Text Article

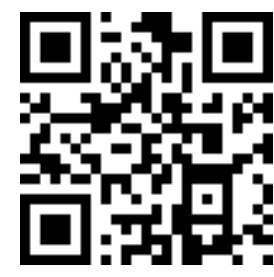

ORCID

() $0000-0002-6431-2594$

Nivedita Sharma

구 0000-0002-1455-611X

Shruti Pathania

(.) 0000-0002-9248-9856

Shweta Handa interest in these microorganisms has increased worldwide owing to their potential commercial application namely production of bioactive compounds, including antibiotics and enzymes (Malherbe and Cloete, 2002; Lynd et al., 2005). Among industrially important enzymes, cellulases and xylanases have attracted the major attention globally 
because of their wide application in many fields. These enzymes fetch extraordinary high prices in the market and main factor responsible for that is the use of expensive substrates like pure cellulose and xylan for production of enzymes.

Xylan is the main component which is present in nature in large amount and major byproduct of farming industry. Xylan (20-30\% of total dry weight of plant biomass) is a heterogeneous polysaccharide consisting of 1,4-glucosidically linked $\beta$-D-xylose with branches containing xylose and other pentose hexose and uronic acids. Due to the structural complexity, biodegradation of xylan require synergetic action of endo-1,4- $\beta$-xylanase (E.C.3.2.1.8) and $\beta$-xylosidase (E.C.3.2.1.37) and several accessory enzymes to hydrolyze the substituted xylan. The expanding area of xylanase application requires a search for novel enzyme and new microbial producers with high specific activities and higher productivity (Ustinov et al., 2008).

Xylanase represents one of the largest group of industrial enzymes with increasing market demands and its applications in prebleaching of kraft pulps, bioconversion of lignocelluloses into feedstocks and fuels (Kim et al., 2000), extraction of coffee and plant oils, improvement of the nutritional properties of agricultural silages and degumming of plant fibres such as flax, sun hemp and ramie (Kuhad et al., 1997; Beg et al., 2001; Subramaniyan and Prema, 2002). In food industry, the enzyme treatments has favourable effects on dough handing, bread volume, texture and stability (Bhat et al., 2001), in improving digestibility of animal feeds (Wong et al., 1988). Xylanase randomly hydrolyze the $\beta$-1,4-glucosidic bonds of xylan to produce xylo-oligomers of different length (Viikari et al., 2007).

Solid state fermentation is an attractive model for fungal enzyme production because it stimulates the natural growth of microorganisms on moist insoluble substrates in the absence or near presence of free liquid facilitating the penetration of mycelia dub into the substrates (Pandey, 2003). It can be performed on a variety of lignocellulosic materials such as rice bran, wheat bran, ragi bran, corn bran, soya bran etc which are proved to be highly efficient in the production of cellulase and xylanase (Sonia et al., 2005). Solid state fermentation is an efficient process to produce enzyme as it is economical due to its lower capital investment and lower operating expenses (Singhania et al., 2009). Utilization of different agricultural/horticultural waste can reduce the economical cost of enzyme and emerge as the industrially important technology as they are available in abundant amount. These materials can be used for by microorganisms as a carbon source results in the production of cellular protein, enzymes, organic acids, biologically important secondary metabolites and oligosaccahrides. Disposal of these waste cause serious environmental problem, not utilizing it may leads to loss of valuable resources.

Therefore the objective of the present research was to optimize the yield of xylanase from using different agricultural/horticultural waste as a carbon source. The cost effective production of xylanase from agricultural waste is economically feasible.

\section{Materials and methods}

\section{Organism and culture}

Myceliopthora thermophila SH1 (A. E. Apinis) C. A. van Oorschot, 1977 (Ascomycota: Chaetomiaceae) sequence had been deposited in Genbank database and provided with an accession number NCBI-JX124712 (Sharma et al., 2013). The stock culture was maintained on agar slants at $5{ }^{\circ} \mathrm{C}$.

\section{Enzyme assays}

Xylanase assay (Miller, 1959): To $0.5 \mathrm{~mL}$ of xylan solution (which was incubated overnight at $37^{\circ} \mathrm{C}$ ) centrifuged and clear supernatant was used, $0.3 \mathrm{~mL}$ citrate buffer was added and $0.2 \mathrm{~mL}$ of enzyme. The control was run with all the components except the enzyme. The reaction mixture was incubated at $45^{\circ} \mathrm{C}$ for $10 \mathrm{~min}$. After the incubation, $3 \mathrm{~mL}$ of DNSA reagent was added and the mixture 
was then heated on boiling water bath for $30 \mathrm{~min}$. After cooling down at room temperature, absorbance of reaction mixture was read at $540 \mathrm{~nm}$. The enzyme activity was expressed in terms of International Unit (IU) and specific activity (SA).

One international unit (IU) of enzyme activity represents $\mu$ moles of xylose released $/ \mathrm{min} / \mathrm{mL}$ of enzyme.

\section{Protein assay}

Protein content of culture filtrate was also determined by Folin-Ciocalteu reagent using bovine serum albumin (BSA) standard (Lowry et al., 1951).

\section{Optimization of carbon source using agricultural wastes on xylanase production}

To elucidate the potential use of agricultural/horticultural waste as the optimized medium formulation on xylanase production was conducted under solid state fermentation was done. By optimization of carbon source using different agricultural wastes in solid state fermentation was done using basal salt medium was prepared with the following composition (g/L): $\mathrm{NH}_{4} \mathrm{SO}_{4}$ 6 g; $\mathrm{KH}_{2} \mathrm{SO}_{4} 3.0$ g; $\mathrm{NaCl} 0.5$ g; $\mathrm{NH} 4 \mathrm{Cl}$ $10 \mathrm{~g} ; \mathrm{MgSO}_{4} 0.2 \mathrm{~mL} ; \mathrm{CaCl}_{2} 0.1 \mathrm{~mL}$; yeast extract $0.5 \%$ distilled water $1,000 \mathrm{~mL}, \mathrm{pH}$ 5.5 as a moistening agent (1:2) after incubation at $45{ }^{\circ} \mathrm{C}$ for 5 days. Thereafter, standard inoculum size was inoculated into culture medium and incubated at $45{ }^{\circ} \mathrm{C}$ at $150 \mathrm{rpm}$ for 5 days. Once the optimized medium formulation was determined, then, the carbon source from the optimized medium formulation was replaced with different agricultural wastes in the subsequent experiments to elucidate the maximum xylanase production in SSF, respectively.

\section{Enzyme extraction}

To $5 \mathrm{~g}$ of untreated and treated biomass of each set $50 \mathrm{~mL}$ of phosphate buffer (0.1 M, pH 6.9) with $0.1 \%$ Tween-80 was added in $250 \mathrm{~mL}$ of Erlenmeyer's flask. The contents were kept under agitation at $120 \mathrm{rpm}$ for $60 \mathrm{~min}$ and then filtered through muslin cloth. The process was repeated twice using $25 \mathrm{~mL}$ of phosphate buffer every time and thus making final volume to $100 \mathrm{~mL}$. After the filtration, contents were centrifuged at $5,400 \mathrm{rpm}$ for $10 \mathrm{~min}$ at $40{ }^{\circ} \mathrm{C}$ (Bollag and Edelstein, 1993). The cell free supernatant was used as the source of crude enzyme preparation and then used for enzyme assay.

\section{Data analysis}

In this study, all of the experiments on the xylanase production under SSF were conducted in duplicate. The mean values of the sampling analysis including xylanase activity, protein assay, generated from the experiments were used to elucidate the production of xylanase by $M$. thermophila SH1 under SSF.

\section{Results and discussion}

The solid state fermentation with
the different waste indicated an accumulated increase in xylanase activity with the time. The total recovered activity of xylanase in orange pulp was higher as compared to other substrates. The yield was $161.20 \mathrm{U} / g d s$ in orange pulp as a substrate after that the sugarcane with $131.40 \mathrm{U} / \mathrm{gds}$ of xylanase was recommended as an effective substrate for xylanase production under solid state fermentation after 5 days of incubation. It is mean that the production of the enzyme seems to be induced when the produced enzyme is frequently removed from the substrate. One can therefore assume a mechanism in equilibrium between the biosynthesis of the enzyme and the free enzyme in solution. Apple pomace also yielded $43.20 \mathrm{U} / g d s$ of xylanase but the enzyme yield decrease as the substrate lignocellulosic structure becomes complex.

Basal salt medium was used as a moistening agent with $\mathrm{pH}$ 5.5. In the present study, reese medium contained a high concentration of the metal ions in the medium, as a result enzyme production was low, which could be due to the blockage of the secretion of protein into external medium (Kaupinen et al., 1997). Basal medium also contained yeast extract which was the most important source of nitrogen in the medium in terms of the accessibility and 
composition to get the higher yield of the xylanase (Sharma and Bajaj, 2005). Basal medium containing $\left(\mathrm{NH}_{4}\right)_{2} \mathrm{SO}_{4}$ and $\mathrm{NH}_{4} \mathrm{Cl}$ as its major ingredients and both being rich source of nitrogen (Briggs et al., 2005) had caused higher xylanase production from bacteria.

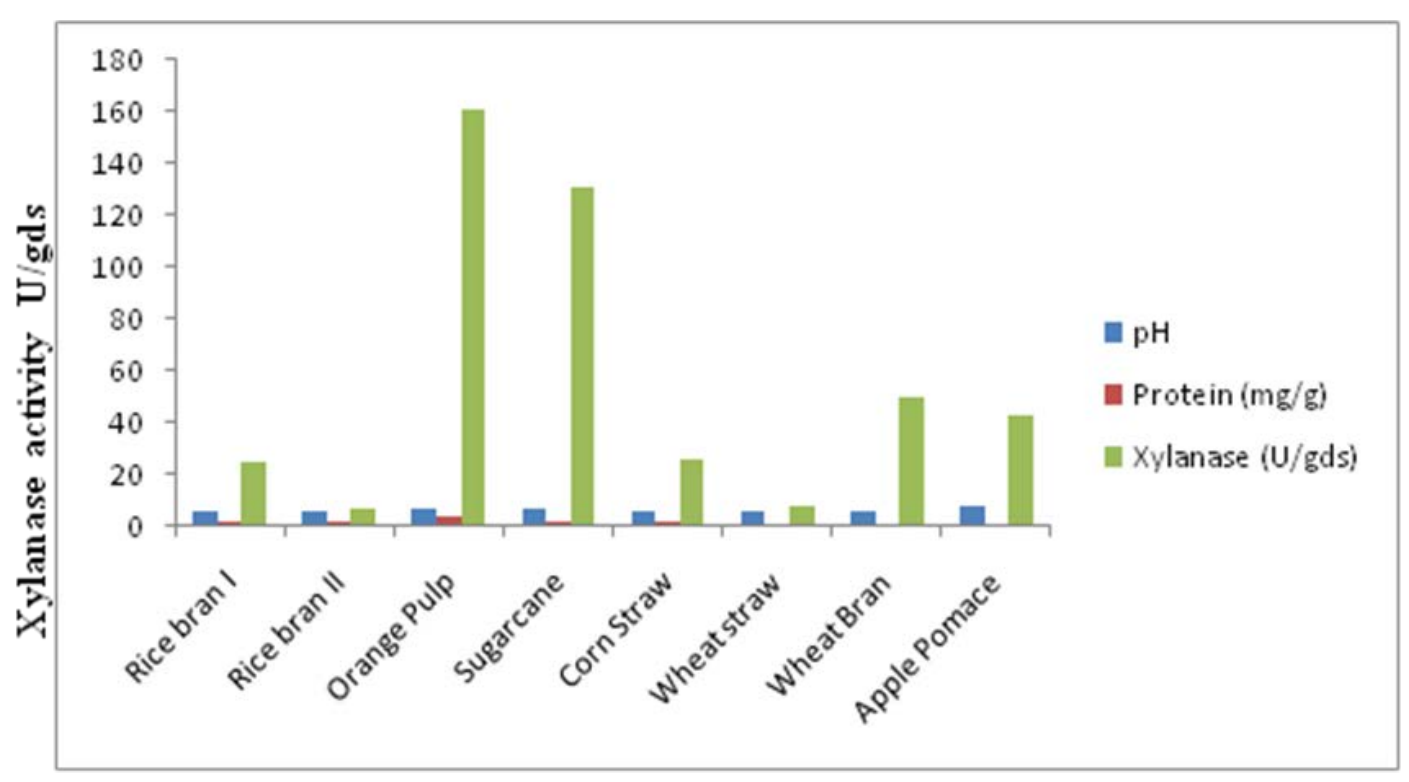

Biomass

Figure 1. Effect of different substarte on xylanase yield under solid state fermentation.

M. thermophila SH1 was capable of growing at high temperature of $45^{\circ} \mathrm{C}$ therefore the xylanase enzyme obtained was alkalo-thermophilic in nature recommending there requirement at industrial scale. Under solid state fermentation the fungus was capable of deep penetration into the substrate thereby breaking down the microfibrilar structure of the substrate, yielding simple substrate for microorganism and enhancing its enzyme production. Agriculture is the mainstay of the people since there are limitations in setting up big industrial units. A large chunk of cultivators is growing mainly food grains crop to meet subsistence needs. This agricultural residue which is generated in huge quantity after agricultural activities in different bread bowl states of India. It doesn't have any direct use and is being burnt by the farmers leading to serious air pollution. This agricultural residue is rich in complex carbohydrate i.e. cellulose and hemicelluloses. Although industrial revolution has changed the world to its sophisticated edge, excessive dependent on fossil fuels as the main source of energy has led to the depletion of this non-renewable supply. Furthermore, demand for petroleum-derived fuels is not slowing down but instead rising substantially over the past few decades. The ever increasing costs of fossil fuels and their greenhouse effects are creating a core demand to explore alternative cheaper and eco-friendly bio-fuels resources as a strategy for reducing global warming. Cost is an important factor for large scale expansion of bioethanol production. The green gold fuel from lignocellulosic wastes avoids the existing competitions of food versus fuel caused by grain based bioethanol production. 


\section{Conclusion}

The xylanase production by M. thermophila SH1 in SSF showed a significant yield from orange pulp as compared to other agricultural and horticultural waste utilized. The majority of these wastes contain cellulose (30-40\%), hemicelluloses (xylan 20-40\%), and lignin (20-30\%). The utilization of these wastes for the production of strategic chemicals and fuel requires hydrolysis of all the components. The use of agro-wastes in the production of such enzymes as xylanases will ultimately bring down their production cost and at the same time reduce environmental pollution due to the wastes.

\section{Acknowledgments}

The funds received from DBT, New Delhi, India, to carry out this work is acknowledged with thanks.

\section{Conflicts of interest}

Authors declare that they have no conflict of interests.

\section{References}

Beg, Q. K.; Kapoor, M.; Bhushan, B.; Hoondal, G. S. Microbial xylanase and their industrial applications: a review. Applied Microbiology and Biotechnology, v. 22, p. 326-338, 2001.

Bhat, M. K. Cellulases and related enzymes in biotechnology. Biotechnology Advances, v. 18, no. $5, \quad$ p. 355-383, 2000. http://dx.doi.org/10.1016/S0734-9750(00) 00041-0

Bollag, D. M.; Edelstein, S. J. Protein methods. New York: Wiley and Sons 1993.

Briggs, S. R.; Cuttle, S.; Goodlass G.; Hatch, D.; King, J.; Roderick, S.; Shepherd, M. Soil nitrogen building crops in organic farming. Defra Research prRoject OF0316. Project publication, 2005.

Kauppinen, T.; Teschke, K.; Savela, A.; Kogevinas, M.; Boffetta, P. International database of exposure measurements in the pulp, paper and paper product industries. Int. Arch. Occup. Environ. Health, v. 70, p. 119-127, 1997.
Kim, J. H.; Kim, S. C.; Nam, S. W. Constitutive over expression of the endoxylanase gene in Bacillus subtilis. Journal of Micrbiology and Biotechnology, v. 10, p. 551-553, 2000.

Kuhad, R. C.; Singh, A.; Eriksson, K. E. L. Microorganisms and enzymes involved in the degradation of plant fiber cell wall. In: Eriksson, K.-E. L.; Babel, W.; Blanch, H. W.; Cooney, Ch. L.; Enfors, S.-O.; Eriksson, K.-E L.; Fiechter, A.; Klibanov, A. M.; Mattiasson, B.; Primrose, S. B.; Rehm, H. J.; Rogers, P. L.; Sahm, H.; Schügerl, K.; Tsao, G. T.; Venkat, K.; Villadsen, J.; von Stockar, U.; Wandrey, C. (Eds.). Biotechnology in the pulp and paper industry. Berlin: Springer-Verlag, 1997. p. 45125. (Advances in Biochemical Engineering and Biotechnology, v. 57). http://dx.doi.org/10.1007/BFb0102072

Lowry, O. H.; Rosebrough, N. J.; Farr, A. L.; Randall, R. J. Protein measurement with the Folin-phenol reagent. Journal of Biology and Chemistry, v. 193, p. 265-275, 1951.

Lynd, L. R.; Zyl, W. H.; McBride, J. E.; Laser, M. Consolidated bioprocessing of cellulosic biomass: an update. Current Opinion in Biotechnology, v. 16, no. 5, p. 577-583, 2005. http://dx.doi.org/10.1016/j.copbio.2005.08.009

Malherbe, S.; Cloete, T. E. Lignocellulose biodegradation: fundamentals and applications. Review in Environmental Sciences and Biotechnology, v. 1, no. 2, p. 105-114, 2002. http://dx.doi.org/10.1023/A: 1020858910646

Miller, G. L. Use of dinitrosalicylic acid reagent for determination of reducing sugars. Analytical Chemistry, v. 31, no. 3, p. 426-428, 1959. http://dx.doi.org/ 10.1021/ac60147a030

Pandey, A. Solid state fermentation. Biochemical Engineering Journal, v. 36, no. 2/3, $\quad$ p. 81-84, 2003. http://dx.doi.org/10.1016/S1369703X(02)00121-3

Sharma, N.; Vyas, G.; Pathania, S. Culturable diversity of thermophilic microorganisms found in hot springs of Northern Himalayas and to explore their potential for production of industrially important enzymes. Scholars Academic Journal of Biosciences, v. 1, no. 5, p. 165-178, 2013. Available from: <http://saspublisher.com/wp-content/uploads/ 2013/10/SAJB-15165-178.pdf>. Accessed on: Jan. 10, 2016.

Sharma, P.; Bajaj, B. K. Production and partial characterization of alkali-tolerant xylanase from an alkalophilic Streptomyces sp. CD-3. Journal 
of Scientific and Industrial Research, v. 64, p. 688-697, 2005. Available from: <http://nopr.niscair.res.in/bitstream/123456789/ 5117/1/JSIR 64(9) 688-697.pdf>. Accessed on: Jan. 10, 2016.

Singhania, R. R.; Patel, A. K.; Soccol, L. R.; Pandey, A. Recent advances in solid state fermentation. Biochemical Engineering Journal, v. 44, no. 1, p. 13-18, 2009. http://dx.doi.org/10.1016/j.bej.2008.10.019

Sonia, K. G.; Chandha, B.; Saini, H. Sorghum straw for hyperxylanase production by Thermomyces lanuginosis (D2W3) under solid state fermentation. Bioresource Technology, v. 96, p. 1561-1569, 2005. http://dx.doi.org/10.1016/j.biortech.2004.12.037 Subramaniyan, S.; Prema, P. Biotechnology of microbial xylanase: enzyme system: biochemistry, molecular biology and application. Critical Reviews in Biotechnology, v. 22, p. 33-64, 2002. http://dx.doi.org/10.1080/07388550290789450

Ustinov, B. B.; Gusakov, A. V.; Antonov, A. I.; Sinitsyn, A. P. Comparison of properties and mode of action of six secreted xylanases from Chrysosporium lucknowense. Enzyme and Microbial Technology, v. 43, p. 56-65, 2008. http://dx.doi.org/10.1016/j.enzmictec.2008.01.017
Viikari, L.; Alapuranen, M.; Puranen, T.; Vehmannpera, J.; Sinitsyn, A. P. Comparative thermostable enzymes in lignocellulose hydrolysis. Advances in Biochemical Engineering Biotechnology, v. 108, p. 121145, 2007.

Wong, K. K. L.; Tan, L. U. L.; Saddler, J. N. Multiplicity of $\beta$-1-4-xylanase in microorganisms: function and applications. Microbiology Reviews, v. 52, p. 305-317, 1998.

License information: This is an open-access article distributed under the terms of the Creative Commons Attribution License, which permits unrestricted use, distribution, and reproduction in any medium, provided the original work is properly cited. 